\title{
PUSHING THE BOUNDARIES: A TENTATIVE TAXONOMY OF MONEY IN NeW Zealand PRIVATE LAW
}

\author{
Matteo Solinas*
}

This article seeks to define the boundaries of money in the context of proprietary taxonomy in New Zealand. It suggests that the traditional legal concept of money exclusively based on state issued (fiat) currency is dated, as does not accommodate the near-universal use of bank money in commercial transactions, nor the recent technological changes introduced by virtual currencies. As long as something functions as a means of payment and the holder has the right to exchange it for legal tender, the divide between mutually agreed payment obligations into those made on the base of fiat currencies and those not, becomes artificial. In providing responses to similar commercial arrangements and parties' legitimate expectations, not only coins and banknotes, but also balances held by customers in banking institutions, foreign money, and digital currencies, should qualify as money for private law purposes.

\section{INTRODUCTION}

Obligations that arise by consent, or that are imposed by law or by statute, require something to be done: a service performed, or goods delivered. Sometimes the obligation is simply to pay money. Even in cases where the initial obligation was for some performance, the law may convert this into an obligation to pay in the form of damages. Money is: ${ }^{1}$

the universal solvent; everything can be turned into money that is either a gain or a loss; money is asked and damages are due for reparation of every possible suffering and injury that a calumny or a libel can inflict on the party affected.

Money traditionally refers to coins and banknotes that circulate according to a payment system created, regulated, and backed by the state. However, with the rise in commercial transactions, alternatives to physical money have been introduced, ranging from "bank money" to forms of electronic money adopted by financial platform firms who use electronic-wallets and payment

* Senior Lecturer in Commercial Law, Te Herenga Waka | Victoria University of Wellington.

1 Auld v Shairp (1874) 2 R 191 (CS) at 199 per Lord Neaves. 
applications. ${ }^{2}$ More recently, new incarnations of money have materialised in the experimental world of "decentralised finance" around cryptocurrencies and, by centralising power in the state, with central bank digital currencies. ${ }^{3}$

This article seeks to define the boundaries of money in New Zealand private law at a time of rapid change. This is a challenging task as the exercise, in addition to purely legal considerations, must also incorporate concepts intrinsic to money's economic functions and the role of the state in the establishment of the monetary system. It has been claimed that a study in the legal taxonomy of money would be trivial ("the proverbial elephant - easy to identify but rather more difficult to define") and that the search for a definition of payment as a way to discharge a monetary obligation could be perhaps more useful. ${ }^{4}$ In the words of Professor Goode: ${ }^{5}$

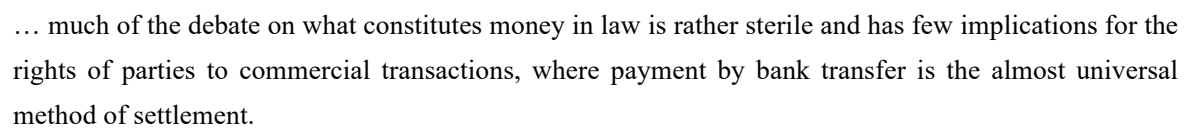

While there are merits in this observation, it is misleading as it is too dismissive of the shift in how money works following the momentous advent of digital currencies outside payments by bank transfer. Moreover, it neglects the very existence of examples in New Zealand legislation where there are important practical consequences depending on whether something is regarded as money or not. ${ }^{6}$ For example, in order to qualify as a sale of goods (and not barter) under the Contract and Commercial Law Act 2017 (the CCLA), the consideration given in exchange must be monetary in form. ${ }^{7}$ Would this provision cover every form of payment different from cash like digital cash (for example, text message through a mobile phone), credit card or virtual currencies?

This article takes a rather prosaic approach. It argues that the question of the legal meaning of money in private law can only be answered by considering the property right regime of the kind of

2 "Bank money" refers to money used for direct payments from a bank account to a person or business. Ewallets and payments applications are both online money transfer services (for example, Paypal, Venmo and TransferWise) and mobile payments (such as WeChat pay, Alipay, Google Pay and Apple Pay).

3 Both open source non-bank digital currencies (for example, Bitcoin, Ether and Litecoin) and corporate-issued digital currencies using a permissioned blockchain (for example, Facebook's Libra/Diem or JP Morgan's JPM coin). Central bank digital currencies refer to digital currency issued as legal tender by a central bank (for example, Chinese digital yuan or the Swedish electronic-krona).

4 Charles Proctor Goode on Payment Obligations in Commercial and Financial Transactions (2nd ed, Sweet \& Maxwell, London, 2009) at 2.

5 Ewan McKendrick Goode on Commercial Law (4th ed, Penguin Books, London, 2010) at 488.

6 In relation to the regulation of financial and money transmission services, see Morris v Ritchie [1934] NZLR s196 (SC) at 197.

7 Contract and Commercial Law Act 2017, s 120; and see Money World New Zealand 2000 Ltd v KVB Kunlun New Zealand Ltd [2006] 1 NZLR 381 (HC) at [68]. 
assets which operate as fungible medium of exchange. ${ }^{8}$ Provided that the holder has a right to exchange them for legal tender, traditional coins and banknotes, but also balances held by customers in banking institutions, foreign money, and digital currencies should all qualify as money for private law purposes.

Part II contemplates the current status of money and shows how its boundaries are perceived. Part III deals with the conventional characterisation of money by focusing on the legal notion of fiat money and the interaction with the various economic rationales. Building on that inquiry, Part IV critically engages with the dichotomy between different forms of debts depending on whether they are made of fiat currency or not. It suggests that as long as money operate as a medium of exchange and the holder maintains the right to exchange them for legal tender, there are not persuasive reasons for private law purposes to restrict the notion of money to only to fiat currencies. Part $\mathrm{V}$ considers certain practical consequences of this approach with respect to the applicability of the bona fide purchaser for value defence. Part VI concludes.

\section{LEGAL UNCERTAINTY}

There is not a general definition of money at common law. Different legal meanings are associated to the word money in New Zealand depending on the specific contexts and various factual circumstances. Sometimes the meaning seems to be technical and narrow. For example, as suggested above, in the case of sale of goods within the scope of the CCLA, a contract for the sale of goods is one "... by which the seller transfers or agrees to transfer the property in goods to the buyer for a money consideration (the price)." ${ }^{9}$ If the transfer is an exchange of goods with no stipulation so as to a money price, it is a barter and is outside the CCLA. However, this approach of statutory derivation can be contrasted with the broader one adopted in an action for "money had and received" where the subject matter is not necessarily money, but everything "that may be readily turned into money". ${ }^{10}$ Or with the case of balances held by customers in banking institutions, which, in the absence of any proprietary links, can be used as a means to discharge financial obligations (and therefore be regarded as customers' money). ${ }^{11}$ Not to mention the broad interpretation offered by the House of Lords in Perrin v Morgan where it was held that a testator who makes a simple will leaving "all my money" to her nephews and nieces "now living" intended to include in the will all the assets that she owned at the date of her death and not just money. ${ }^{12}$

8 BP Exploration (Libya) Co Ltd v Hunt (No 2) [1979] 1 WLR 783 (QB) at 799; and see also David Fox Property Rights in Money (Oxford University Press, Oxford, 2008) at 10.

9 Contract and Commercial Law Act, s 120.

10 Spratt v Hobhouse (1827) 4 Bing 173 (Comm Pleas) at 179.

11 Foley v Hill (1848) 2 HL Cas 28.

12 Perrin v Morgan [1943] AC 339 (HL). 


\section{THE CONVENTIONAL APPROACH}

Against such equivocally conceptualised background, this article seeks to define the boundaries of money in the context of proprietary taxonomy in New Zealand. ${ }^{13}$ Historically, the conventional way of distinguishing between money and non-money assets for the purpose of private law has been to limit the definition only to the cases where a formal and mandatory backing of the domestic legal system as expression of monetary sovereignty was provided.

Already in 1938, Dr Mann tried to reconcile certain standard economic functions of money and the assets that could be considered money according to a legal definition. He wrote: ${ }^{14}$

It is suggested that in law the quality of money is to be attributed to all chattels which, issued by the

authority of the law and denominated with reference to a unit of account are meant to serve as a universal

means of exchange in the State of issue.

This view is generally labelled as the State Theory of money as it is based on the role of the state in setting out the monetary system and in authorising the issue of notes and coins serving as universal means of exchange within that state. Money is deemed by the state to have a particular value (fiat money).

That money must exist within a legally defined framework to qualify as such is now also expressly provided in New Zealand by the Personal Property Securities Act 1999 (the "PPSA") where it is stated that money means "currency authorised as a medium of exchange by the law of New Zealand or of any other country". 15

\section{A The Issue of Money}

Under s 10(1)(a)(i) of the Reserve Bank of New Zealand Act 2021 (the "RBNZ Act"), New Zealand currently retains and exercises sovereignty in monetary matters. Coins and banknotes (including their denominations, form, design, content, weight and composition) are issued by the Reserve Bank of New Zealand. ${ }^{16}$ They enjoy legal recognition as a national unit of account in New

13 For a comprehensive analysis of the issue and further references, see Andreas Rahmatian Credit and Creed: A Critical Legal Theory of Money (Routledge, England, 2019) at 2-8.

14 Frederik Alexander Mann The Legal Aspect of Money (Oxford University Press, Oxford, 1938) at 7.

15 Personal Property Securities Act 1999, s 16(1) [PPSA]. Similarly, under the Uniform Commercial Code UCC Para 1-201 (24) (US), money is a "medium of exchange authorised or adopted by a domestic or foreign government as part of its currency".

16 Reserve Bank of New Zealand Act 2021, s 149 [RBNZ Act]. The Reserve Bank of New Zealand's sole right of issue includes the issuances before the commencement of RBNZ Act, and every coin issued by the Minister under the Decimal Currency Act 1964 or under the Coinage Act 1933 by virtue of the Decimal Currency Act 1964, which is legal tender at the commencement of Reserve Bank of New Zealand Act 1989. 
Zealand, passing as legal tender in payment of debts. ${ }^{17}$ While coins are technically chattels personal (meaning, choses in possession), banknotes are promissory notes made payable to the bearer. Banknotes are therefore documentary intangibles (meaning, choses in action) in which the paper form embodies a legally enforceable promise to pay. ${ }^{18}$ This is because, historically, banknotes were issued by private bankers as slips for recording a customer's deposit of coins with the bank or the amount of a loan provided by the bank. ${ }^{19}$ They later became transferable by delivery, like coins, and redeemable to the new holder. The banknotes ceased to be treated as a claim to be paid in the form of coins and became a medium of exchange in their own right (meaning unnecessary to be redeemed): ${ }^{20}$

Provided that the issuing bank's credit was good, and every holder could remain confident of his or her ability to redeem the note if and when he or she wanted to ...

That said, in the case of banknotes, the bearer's claim is no longer redeemed by the Reserve Bank of New Zealand in gold or other precious metal. ${ }^{21}$ Hence, banknotes today are pure fiat money with nominal value independent of the intrinsic value of the paper and used as a medium of exchange. ${ }^{22}$ They can be deposited in a bank account or surrendered for money in different denominations, operating, therefore, as choses in possession. ${ }^{23}$ Money in New Zealand can also be the subject of a security interest perfected by possession or by registration of a financing statement of a personal property under PPSA. ${ }^{24}$

17 RBNZ Act, ss 152-153.

18 Michael Bridge Personal Property Law (Oxford University Press, Oxford, 2015) at 19.

19 Andrew Crockett Money: Theory, Policy and Institutions (Thomas Nelson \& Sons Ltd, London, 1973) at 17 18.

20 Fox, above n 8, at 11.

21 Banknotes ceased to be convertible into sovereign coins in 1914 by proclamation (Banking Amendment Act of 1914), later confirmed by statute in the Gold Standard Act 1925, s 1(1) and Gold Standard (Amendment) Act 1931, s 1. See Glyn Davies A History of Money: From Ancient Times to the Present Day (University of Wales Press, Cardiff, 2002) at 366-375; and Gary Richard Hawke The Evolution of New Zealand Currency (Victoria University of Wellington Press, Wellington, 1984) at 16.

22 Banco de Portugal v Waterlow \& Sons Ltd [1932] AC 452 (CA) at 460 per Viscount Sankey LC.

23 David Fox "Bona Fide Purchase and the Currency of Money" (1996) 55(3) CLJ 547 at 555.

24 A holder of money takes free of a perfected security interest if either the money is acquired without knowledge of the interest or the holder is a holder for value: PPSA, s 94. 


\section{B The Functions of Money}

The theory that identifies what counts as money to chattels recognised by the state is usually associated to the fulfilment of certain functions. In particular, economists have identified the main functions of money into three categories: ${ }^{25}$

(a) Medium of exchange with which to make payments for goods and services. ${ }^{26}$ This function historically served to overcome the inconvenience (and transaction costs) ${ }^{27}$ of concluding exchange transactions by barter with the acceptance of a highly saleable commodity in return for another commodity. ${ }^{28} \mathrm{~A}$ commodity becomes a proxy to facilitate the effective exchange of goods and services when it is stable in preserving its value against consumption commodities, fungible in its content with any other unit of it of equal value and of a value recognisable by anyone who accepts it in an exchange transaction. ${ }^{29}$

(b) Unit of account with which to measure the value of a particular good, service, saving or loan. The existence of a common denominator of value to establish the exchange ratios between commodities is essential also in a barter economy.

(c) Store of value or wealth with which to transfer purchasing power from today (the original receipt) to some future time (meaning, the subsequent utilisation by the holder as a means of payment). ${ }^{30}$ The distinguishing feature of using money as store of value instead of other assets is that "the value inhering within it is always expressed in terms of a constant number of units of account". 31

\section{Money as a Commodity}

There are circumstances where money should be treated as a commodity rather than as a medium of exchange. The case of coins that have a value by reference to their rarity over and above their nominal value is a typical example. ${ }^{32}$

25 Mervyn Lewis and Paul Mizen Monetary Economics (Oxford University Press, Oxford, 2000) at 5-6; and Frederic Miskin The Economics of Money, Banking and the Financial Markets (10th ed, Pearson, London, 2014) at 9.

26 Robert A Jones "The Origin and Development of Media of Exchange" (1976) 8 J Pol Econ 757; and Nobuhiro Kiyotaki and Randall Wright "On Money as a Medium of Exchange" (1989) 97 J Pol Econ 927.

27 Transaction costs are the cost of finding another person in the market willing to make a direct exchange of commodities.

28 This theory was first elaborated by Karl Menger "On the Origin of Money" (1892) 2 Econ J 239.

29 Crockett, above $\mathrm{n} 19$, at chapter 1.

30 Lewis and Mizen, above n 25, at 10-11.

31 Fox, above $\mathrm{n} 8$, at 9.

32 Moss v Hancock [1899] 2 QB 111. 
Another important historical case is the one relating to foreign money where a failure to pay an amount due in foreign currency was regarded as a (contractual) failure to delivery rather than an action in debt. ${ }^{33}$ According to this interpretation, foreign banknotes held in another state were not to be regarded as legal tender, but commodities. ${ }^{34}$ However, following the England and Wales Court of Appeal decision in Camdex International Ltd $v$ Bank of Zambia (No 3), this is not the case anymore. ${ }^{35}$ The dispute centred on whether a Zambian metal trader, required by Zambian law to remit a certain percentage of its foreign currency earnings to the Bank of Zambia in return for local currency, was indebted to the bank. While Phillips LJ argued that coins and notes could be transferred by reference to their intrinsic value in the same way as commodities were also transferred, he also suggested that: ${ }^{36}$

whether money is lent or borrowed, whether it is used to buy goods or services, or whether it is exchanged

against a different currency, it retains its character as a medium of exchange ... The fact that the identity

of the currency may be a material feature of the transaction does not translate the currency into a

commodity, whatever the nature of the transaction.

A number of statutes in New Zealand today confirm that foreign money is to be treated on the same footing as money and obligations expressed in New Zealand currency. For example, s 239AEH of the Companies Act 1993 provides that when the company is in voluntary administration the rules on set-off and netting set out under ss 239AEI-239AEP apply to all obligations under a netting agreement, whether those obligations are payable in New Zealand currency or in some other currency.

\section{ASSETS THAT FULFIL MONETARY FUNCTIONS}

The just-described conventional legal notion of money is not the only possible one. Nor does it offer the most accurate account of the meaning of money. It fails to incorporate important developments in market practice driven by the continuous search for rapid and efficient means of transferring monetary value and effecting payment.

The idea that money exists as some form of chattel (meaning, in physical form), that all the economic criteria that describe its functions are equally relevant for legal purposes and that the state has a monopoly over its creation is not a convincing legal characterisation of money anymore. ${ }^{37}$ It assumes that people only use (and that in the near future will continue to use) pieces of paper and metal in exchange for goods and services when it is apparent that these today only settle small-scale

33 Moll v Royal Packet Navigation Ltd (1952) 52 SR (NSW) 187.

34 Marrache v Ashton [1943] AC 311 (PC); A Ltd v B Bank [1997] 6 Bank LR 85 (CA); and, similarly, in the US the Court of Appeals Vishipco Lines v Chase Manhattan Bank 754 F 2d 452 (2d Cir 1985) at 458.

35 Camdex International Ltd v Bank of Zambia (No 3) [1997] EWCA Civ 798.

36 At 719.

37 See Ludwig von Mises The Theory of Money and Credit (H E Batson (translator), Jonathan Cape, London, 1953 ) at 69. 
retail transactions. ${ }^{38}$ Moreover, it does not capture payments made through the inter-bank system to the point that, in the absence of a contrary agreement, even a payment by cheque can be refused by a creditor as it does not qualify as a legal tender. ${ }^{39}$ Further, if money serves as a means of discharging obligations which are expressed in monetary terms, it does not provide a rationale for not including in its coverage other assets issued, arranged and administered by private entities to the extent that they constitute a fungible medium of exchange and give the holder the right to exchange them for legal tender. Finally, the same economic idea that money must be necessarily denominated by reference to a distinct unit of account is redundant from a purely legal perspective if, as long as chattels remain convertible into national currency, it fails to include "anything more than the simple embodiment of a unit of account" (for example, coins and banknotes). ${ }^{40}$ And similarly, that money should be regarded as a store of value "perhaps reflects the economic view of money, rather than its purely legal aspects". 41

The status of an asset as money that functions as a medium of exchange is rather a social fact that must be accepted in the community where it circulates and becomes relevant in private law when the holder has a right to exchange it for legal tender. ${ }^{42}$ This view originates from the intuition contained in the Societary Theory of money, according to which the recognition of money results from social usage alone. ${ }^{43}$ However, it also appropriately reconciles with the fundamental idea that without the formal and mandatory backing of the domestic legal system where it circulates, money as a means of exchange does not reflect an exercise of monetary sovereignty and cannot be considered money in the legal sense. The case of "private money" offers a good example of a currency used as a means of payment within a particular community that has to be regarded as money in the legal sense. ${ }^{44}$ It operates as a means of exchange, even if it is not a fiat currency backed by the state, reflecting effectively a complementary currency that works alongside the national currency, trading at par with it. As Professor Bridge puts it: ${ }^{45}$

38 In New Zealand they represent less than 10 per cent of the money that circulate. See Gillian Lawrence "The Reserve Bank, private sector banks and the creation of money and credit" (2008) 71(1) Reserve Bank of New Zealand: Bulletin 25; and Michael Burda and Charles Wyplosz Macroeconomics: A European Text (6th ed, Oxford University Press, Oxford, 2013) at 207.

39 Gordon v Strange (1847) 1 Ex 447 (Exch).

40 Proctor, above $\mathrm{n} 4$, at 28.

41 At 29.

42 Lewis and Mizen, above n 25, at 22.

43 Moss v Hancock, above n 32, at 116; and Fox, above n 8, at 7-8.

44 Proctor, above $\mathrm{n} 4$, at 35.

45 Michael G Bridge Benjamin's Sale of Goods (10th ed, Sweet \& Maxwell, London, 2016) at [1.034]. 
payment using 'money' issued by local communities or traders, such as the Brixton pound in London, may constitute money for the purposes of a sale contract where the scheme gives holders of the notes the right to exchange them for legal tender in so far as a holder of such a note uses it to pay for goods.

The inquiry below builds on this notion of money structured around the criterion of a medium of exchange, without limiting it to fiat currencies, whenever the holder maintains the right to exchange it for legal tender. In particular, it identifies four cases which would not otherwise qualify as money according to the orthodox private law interpretation: bank money, electronic money, cryptocurrencies and central bank digital currencies.

\section{A Bank Money}

Bank deposits are debts held by customers that give them an entitlement to draw upon the credit balance with the bank or to instruct the bank to make payment on their behalf. ${ }^{46}$ Even if they are not technically legal tender, they can still be used as a means of discharging financial obligations and reduced to payment by the delivery of legal tender at par value. ${ }^{47}$

If money is an abstract concept not limited to physical chattels, there should be some common characteristics between coins, banknotes and bank money. There is not a complete overlap. It is perhaps sufficient to observe that the possibility of losses for account holders in the case of bank insolvency does not have relevance for the holders of banknotes and coins. Or the circumstance that banknotes and coins are exposed to the risk of loss through theft, a risk that does not arise in relation bank deposits. However, when focusing on their functional similarities as means of payment, banknotes and coins are identical to bank money. A clear example is the case of the payee who acquires good title to banknotes and coins in the settlement of a transaction when possession of banknotes and coins is transferred. ${ }^{48}$ Even if technically the credit of funds in the payee's account in the case of a bank transfer involves a form of novation (meaning an equal and opposite debiting of the payer's account and crediting of the payee's account), ${ }^{49}$ this is functionally identical to the transfer of banknotes and coins. ${ }^{50}$ Not to mention that as a creditor who receive banknotes and coins in discharge of a debt will be unconcerned with the credit standing of the debtor, a creditor who receives

46 Foley v Hill, above n 11.

47 See Proctor, above n 4, at 37-43, who compares payments in physical cash and payments by bank account transfer, finding out important similarities in the fact that they are both irrevocable and both confer "possession" of the funds and good title on the recipient, even if, technically, they are choses in possession and choses in action, respectively.

48 Bank Belge v Hambrouck [1921] 1 KB 321 at 329.

$49 R$ v Preddy [1996] AC 815 (HL).

50 Tayeb v HSBC Bank plc [2004] EWHC 1529 (Comm). 
payment by credit to his bank account will be unconcerned with the state of the debtor's account. ${ }^{51}$ In both cases, payment will simply be considered as "final".

\section{B Electronic Money}

Electronic money is an electronic alternative for coins and banknotes. It usually consists of a prepaid account on an electronic device such as a mobile telephone (for example, Apple Pay) or a cardbased product ${ }^{52}$ which electronically stores "monetary value as represented by a claim on the issuer which is issued on receipt of funds for the purpose of making payment transactions". ${ }^{53}$ It may also consist in "digital cash" that allows a person to upload funds from a bank account or credit card to an internet based account that may be used to pay for goods and services (for example, PayPal). Like bank money, electronic money is not issued by the state and is not tangible property or legal tender. Still, it is denominated in a "sovereign fiat" unit of account. It is a medium of exchange and capable of legally circulating in the same way as coins and banknotes. ${ }^{54}$

\section{Cryptocurrencies}

Cryptocurrencies are another form of non-physical money that functions outside the traditional banking system. As long as they ensure payment for goods and services by the transfer of value, they should also qualify as money in private law. ${ }^{55}$ Cryptocurrencies are difficult to square within the traditional boundaries of personal property, as they are not technically choses in action nor choses in possession. ${ }^{56}$ In the language of the Bitcoin Whitepaper, bitcoins, for example, are transferred, stored

51 Lloyds Bank plc v Independent Insurance Co Ltd [1998] EWCA Civ 1853; and see Proctor, above n 4, at 7.

52 On currency-based, account-based, and note-based payment systems, see James Steven Rogers "The New Old Law of Electronic Money" (2005) 58(4) SMU L Rev 1253; David Kreltzheim "The Legal Nature of Electronic Money" (2003) 14 JBFLP 161; and for general comparative discussion on the subject, see also Committee on Payment and Settlement Systems Survey of Electronic Money Developments (Bank of International Settlements, May 2000).

53 European Parliament and Council Directive 2009/110/EC, art 2(2), on the taking up, pursuit and prudential supervision of the business of electronic money institutions, amending Directives 2005/60/EC and 2006/48/EC and repealing Directive 2000/46/EC (the "Electronic Money Directive").

54 Robert C Effros "Electronic Payment Systems: Legal Aspects" in Norbert Horn (ed) Legal Issues in Electronic Banking (Kluwer Law International, The Hague, 2002) 189.

55 Michael Bridge, Louise Gullifer, Gerard McMeel and Kelvin Low The Law of Personal Property (2nd ed, Sweet \& Maxwell, London, 2017) 163; and Aaron Kumar and Christie Smith Crypto-currencies - An introduction to not-so-funny moneys (Reserve Bank of New Zealand Analytical Note Series, AN2017/07, November 2017).

56 "All personal things are either in possession or action. The law knows no tertium quid between the two": Colonial Bank v Whinney (1885) 30 Ch D 261 (CA) at 285-286 per Fry LJ, whose dissenting judgment was upheld in Colonial Bank $v$ Whinney (1886) 11 App Cas 426 (HL). The authority for this dichotomy can be traced in William Blackstone Commentaries on the Laws of England (vol 2, facsimile ed, University of Chicago Press, Chicago, 1766, 1979) at 396-397. 
and lost in ways that closely mirror the way according to which choses in possession (meaning tangible things of which physical possession can be taken and rights in relation to which can be asserted by use and enjoyment) are regulated. ${ }^{57}$ However, technically cryptocurrencies are intangibles and therefore incapable of being possessed. They are simply a string of data that records a transactional output of value at the public key of the person entitled to use it ("unspent transaction outputs"). Under the law, a proprietary action in the law of torts, such as conversion, requires a proof of actual interference with possession or a right to immediate possession. ${ }^{58}$ The exercise of control over access to it is usually not sufficient. Notwithstanding some critical views, ${ }^{59}$ physical control over a tangible thing is required. ${ }^{60}$ Hence, according to the conventional legal classification of personal property, cryptocurrencies are not choses in possession. That said, cryptocurrencies do not qualify as choses in action (meaning property rights that can only be obtained or enforced through legal action) either. They are intangibles, but they operate differently from, for example, traditional bank money. The chain of digitised information that forms a bitcoin is not a legal claim for the payment of money in the form of a legal tender like a bank debt. ${ }^{61}$ As the bitcoin protocol does not require the involvement of a centralised intermediary that holds the ledgers recording the customer's accounts and validates the transfer when sufficient funds are available in the account, it is impossible to identify a person against whom action could be taken to vindicate those proprietary rights. In short, there is no one to take on the role of a debtor or obligor within the bitcoin network.

Nevertheless, as suggested by Mr Stephen Morris QC, sitting as Deputy High Court Judge in Armstrong DLW GmbH v Winnington Networks Ltd, ${ }^{62}$ a broader definition of personal property is possible at common law, consisting of the right to exclude others from a resource whatever form the exigibility (rights in personam or in rem) and content (for example, to make a payment) may take, capable to cover both tangible and intangible things. ${ }^{63}$ Essentially, this is a hybrid form of "intangible

57 Satoshi Nakamoto "Bitcoin: A Peer to Peer Electronic Cash System" (Bitcoin, Whitepaper, 2008) at 2.

58 Only a chose in possession can be the subject of an action in conversion. See OBG Limited v Allan [2007] UKHL 21 per Lord Nicholls of Birkenhead.

59 Sarah Green and John Randall The Tort of Conversion (Hart Publishing, Oxford, 2009) at 107-146.

60 Your Response Limited v Datateam Business Media Limited [2014] EWCA Civ 281 at [9]-[10] per MooreBick LJ and [38]-[39] per Davies LJ. This was also confirmed in the England and Wales Court of Appeal decision in The Environment Agency v Churngold Recycling Ltd [2014] EWCA Civ 909.

61 When a customer deposits money in a bank account, the bank ordinarily becomes the owner of the funds, as established by the House of Lords in Foley v Hill, above n 11, at 1005 per Lord Cottenham.

62 Armstrong DLW GmbH v Winnington Networks Ltd [2012] EWHC 10 (Ch), [2013] Ch 156.

63 Kelvin F K Low "Equitable Title and Economic Loss" (2010) 126 LQR 507. 
property"64 that characterises cryptocurrencies as choses in action that do not resist the notion of legal proceedings being brought to assert entitlements against third party interferers and, at the same time, as things in their own right that share some of the essential characteristics of choses in possession. This reading is consistent with the ruling of Lord Wilberforce in National Provincial Bank $v$ Ainsworth that identifies a right or an interest capable of being admitted into the category of property, or of a right affecting property as: ${ }^{65}$

definable, identifiable by third parties, capable in its nature of assumption by third parties and have some

degree of permanence or stability the fundamental characteristics of property in the following way.

Building on that approach, export quotas, milk quotas, waste management licences and carbon trading allowances have been held to be property when they have acquired economic value and shown themselves susceptible to transfer and trade. ${ }^{66}$ It can be argued that the analogy should be extended to cryptocurrencies, as they are computer-readable strings of characters definable on the basis of the distinctive blockchain transactional history, identifiable by the holder's exclusive control over the private key (associated with the public key), capable of being transferable to system participants and, as with other conventional financial assets, permanent and stable in their nature, given the underlying blockchain technology. ${ }^{67}$

That cryptocurrencies are property is the view of the United Kingdom Jurisdiction Taskforce today, ${ }^{68}$ supported by the majority of academic commentators, ${ }^{69}$ and recently endorsed in New

64 Attorney-General of Hong Kong v Nai-Keung [1987] 1 WLR 1339 (PC) at 1342; Fox, above n 8, at 153; and Frederik Henry Lawson and Bernard Rudden Lawson and Rudden on the Law of Property (Oxford University Press, Oxford, 2002) at 29.

65 National Provincial Bank v Ainsworth [1965] 1 AC 1175 (HL) at 1247-1248 per Lord Wilberforce.

66 Attorney-General of Hong Kong v Nai-Keung, above n 64, at 1342; Swift v Dairywise Farms Ltd [2000] 1 WLR 177 (CA); Re Celtic Extraction Ltd (in liq) [2001] Ch 475 (CA) at [49] and [58]-[61]; Armstrong DLW GmbH v Winnington Networks Ltd, above n 62; and a critical analysis of the case is provided by Kelvin F K Low and Jolene Lin "Carbon Credits as EU Like It: Property, Immunity, TragiCO2medy?" (2015) 27 JEL 377.

67 This interpretation is provided by David Fox "Cryptocurrencies in the Common Law of Property" in David Fox and Sarah Green (eds) Cryptocurrencies in Public and Private Law (Oxford University Press, Oxford, 2019) 153; David Fox "Cyber-currencies in private law" in Shelley Griffiths, Mark Henaghan and M B Rodriguez Ferrere (eds) The Search for Certainty: Essays in Honour of John Smillie (Thomson Reuters, Wellington, 2016) 139; and Lucy Chambers "Misappropriation of cryptocurrency: propelling English private law into the digital age?" (2016) 5 JIBFL 263.

68 United Kingdom Jurisdiction Taskforce Legal statement on cryptoassets and smart contracts (The Law Tech Delivery Panel, November 2019) at [39]-[58].

69 "Cryptocurrencies in the Common Law of Property", above n 67; and Kelvin FK Low and Ernie GS Teo "Bitcoins and other cryptocurrencies as property?" (2017) 9 Law Innov Technol 235 at 249-252. 
Zealand by Gendall J in Ruscoe v Cryptopia Ltd (in liq). ${ }^{70}$ Even if cryptocurrencies are not issued by the state but are governed by a privately created protocol that does not confer any legal tender status, there is no reason to treat them differently from bank money or electronic money. ${ }^{71}$ As held by the Court of Justice of the European Union in Skatteverket $v$ Hedqvist in the context of the European Union's Value Added Tax Directive, the only significant differences with bank money are that cryptocurrencies are not denominated in a private unit of account authorised by the state and that they can only be exchanged for conventional currencies. ${ }^{72}$ In essence, the status of cryptocurrencies is analogous to that of foreign money, "analogous to other convertible currencies as regards their use in the real world."73 Similar to bank money, while they cannot purchase articles of commerce or satisfy a debt unless expressly stipulated for by the creditor, they are to be regarded as money at law.

\section{Central Bank Digital Currencies}

A more recent development in the direction of cashless transactions has been the launch of central banks digital currencies (CBDC) ${ }^{74}$ possibly as a way to lessen the danger to financial stability from reliance on purely private payment systems, such as peer to peer payment platforms (for example PayPal). CBDCs are different from the reserve balances held by commercial banks with the central bank ${ }^{75}$ and are designed to be available to individuals, households and businesses in order to be used as a general unit of account, store of value and means of payment. They are a digital form of cash (the physical money issued by central banks). They represent a claim on the central bank. Contrary to electronic deposits held in a commercial bank, which are merely claims on that commercial bank, money held on a CBDC application or website are equivalent to a deposit at the central bank and they are guaranteed by the full faith of the state, not a fallible bank.

There are still unresolved issues on how to design "retail" digital currencies for the public, including whether a CBDC should be held and transferred on a distributed ledger or by means of a more traditional centralised book-entry system, whether the digital wallets in which the public would

70 Ruscoe v Cryptopia Ltd (in liq) [2020] NZHC 728.

71 "Anything which is legal tender must be money, but not all money is legal tender": Proctor, above n 4, at 46.

72 Case C-264/14 Skatteverket v Hedqvist [2016] STC 372 (CJEU) at [12]. A similar interpretation has been put forward in the United States in Securities and Exchange Commission v Shavers (Case No 4:13-CV-416-RCALM, 6 August 2013) at 1-3; United States v Ulbricht (Case No 1:14-CR-068-KBF, SDNY, 9 July 2014), 5 at [47]-[50]; United States v Faiella (Case No 1:14-CR-243-JSR, SDNY, 8 August 2014), 2-3; and United States v Murgio (Case No 1:15-CR-769-AJN, SDNY, 19 September 2016).

73 Bitcoins "are analogous to other convertible currencies as regards their use in the real world": Skatteverket, above $\mathrm{n} 72$, at [12].

74 Raphael Auer, Guilio Cornelli and Jon Frost Rise of the Central Bank Digital Currencies: Drivers, Approaches and Technologies (Bank for International Settlements, Working Paper No 880, August 2020).

75 Michael Kumhof and Claire Noone "Central Bank Digital Currencies-Design Principles and Balance Sheet Implications" (Bank of England, Working Paper No 725, May 2018). 
hold CBDCs should be managed by the national central banks or commercial banks and what level of security and privacy should be provided to CBDC users. While countries experiencing a declining use of cash are considering whether a CBDC could provide an additional form of legal tender, ${ }^{76}$ others which primarily rely on cash are investigating the potential for CBDCs as a way to increase financial inclusion and support the unbanked population move into the formal banking sector, boosting economic development. ${ }^{77}$ At present, there is no immediate prospect to issue CBDCs in New Zealand. ${ }^{78}$

\section{MONEY AND NEGOTIABILITY}

The discussion on the legal characterisation of money is not merely theoretical. Depending on the adopted definition, certain important legal consequences should be taken into account. Assuming that it is possible to have proprietary rights in (tangible and intangible) money, it is important to establish whether property rights are always withheld or, alternatively, enforced but subject to a wide negotiability exception.

Under New Zealand law there is no general defence of good faith purchase for the innocent acquirer for value of title to property that the seller did not have to give (per nemo dat quod non habet). Security of ownership almost invariably takes priority over security of transaction. Hence, the transferee takes legal title to property subject to prior interests affecting the estate. It is irrelevant that the transferee acted in good faith. With reference to personality ${ }^{79}$ Cleasby $\mathrm{J}$ in Fowler $v$ Hollins described this rule as follows: "persons deal with the property in chattels or exercise acts of ownership over them at their peril." 80

76 In Sweden the Riksbank is investigating whether it is possible to issue a digital complement to cash, a socalled e-krona. Just like cash, the e-krona would be issued by the Riksbank and be available to the general public: see Sveriges Riksbank "E-krona" (24 April 2021)<www.riksbank.se>.

77 The Central Bank of the Bahamas has launched a CBDC pilot called "Project Sand Dollar" with the goal of increasing financial inclusion across the islands in the Bahamas: see Sand Dollar "About Us" $<$ www.sanddollar.bs $>$.

78 Christian Hawkesby, RBNZ Assistant Governor "Working together to be 'on the money'" (speech delivered to The Royal Numismatic Society of New Zealand, Annual Conference, Wellington, 19 October 2020).

79 So far as realty is concerned, "it is perhaps because the nemo dat principle is so fundamental that it is difficult to find examples of it at work in the case of common law interests": William Swadling (ed) "Restitution and Bona Fide Purchase" in The Limits of Restitutionary Claims: A Comparative Analysis (United Kingdom Comparative Law Series, vol 17, London, 1997) 79 at 80; and see also Louise Merrett "The Importance of Delivery and Possession in the Passing of Title" (2008) 67 CLJ 376.

80 Fowler v Hollins (1872) LR 7 QB 616 at 639, approved in Hollins v Fowler (1875) LR 7 HL 757; and see also Farquharson Bros \& Co v King \& Co [1902] AC 325 (HL). 
However, a number of exceptional circumstances at common law and specific statutory provisions confer to an innocent purchaser for value a title to property, which its vendor did not have to give. ${ }^{81}$ An important defence applies to money. This legal characterisation creates an indefeasible legal title in a transferee who receives money in good faith and for value from someone who does not have legal title. The recipient is immune from the claims of previous holders who still have a proprietary interest in money. The original rationale for the defence in the case of money concerned the need to reduce parties' transaction costs and in particular, the evidential problem of proving title to coins that are possessed by another person (the "no earmark rule"). ${ }^{82}$ It was then extended by adopting a substantive rather than evidential rule to provide for the currency of money in the eighteenth century to paper money in the form of promissory notes payable to bearer or order. In that respect, Lord Manfield in Miller $v$ Race provided that an original owner could not sue to enforce a legal title to money once it was "paid away fairly and honestly upon a valuable and bona fide consideration". ${ }^{83}$ Later in time, when it was accepted that a bank receiving trust money in good faith and in discharge of its customer's overdraft takes an indefeasible title to it, ${ }^{84}$ it became possible to argue that the defence also covered bank money in the form of choses in action. ${ }^{85}$ The rationale behind that extension was to facilitate effective commercial expectations of the parties who regarded bank money as being synonymous for all practical purposes with notes and coins. If that reading is correct, there is no substantial reason today to deny that the defence could be extended to any kind of money, including electronic money, cryptocurrencies and central bank digital currencies when they are transferred from one person to another as a means of payment. Their differences, after all "lies not in their private law function as between contracting parties, but in their public status." ${ }^{86}$ Some operate as tools of governmental policy and others are independent of it.

\section{CONCLUSIONS}

This article has argued that the traditional legal characterisation of money based on the divide between debts made on fiat currency or not is outdated. As long as chattels are regarded as medium of exchange and the holder has the right to exchange them for legal tender, they should qualify as

81 See the critical account of the rule and its exceptions contained in JWA Thornely "Thieves, Rogues, Innocent Purchasers and Legislatives Tangles" (1988) 47 CLJ 15. Particular consideration should also be given to the doctrinal analysis made by Tony Weir "Taking for Granted - the Ramifications of Nemo Dat" (1996) 49 CLP 325 and Iwan Davies "Transferability and Sale of Goods" (1987) 7 LS 1.

82 Fox, above n 8, at 270-271.

83 Miller v Race (1757) 1 Burr $452(\mathrm{~KB})$ at 457.

84 See Barclays Bank Ltd v Quistclose Investments Ltd [1968] 3 WLR 1097, [1970] AC 567 (HL); and Bishopsgate Investment Management Ltd (in liq) v Homan [1994] 3 WLR 1270, [1995] 1 All ER 347 (CA).

85 Fox, above n 8, at 325 .

86 Sarah Green "It's Virtually Money" in Green and Fox Cryptocurrencies in Public and Private Law (Oxford University Press, Oxford, 2019) 30. 
money. If "bank money" is commonly and continuously accepted as payment in exchange for articles of commerce, it means that the State Theory of money which limits the notion of money to legal tender is fundamentally flawed. It is only by embracing the theory that treats money as a means of exchange accepted by commerce and society as a means of payment that bank money, electronic money, cryptocurrencies and central bank digital currencies can legitimately qualify as money for the purpose of New Zealand private law.

The property law principle according to which if the owner of money loses the possession of it, he loses the property in it can be justified because: ${ }^{87}$

by the use of money the interchange of all other property is most readily accomplished. To fit it for its purpose the stamp denotes its value, and possession alone must decide to whom it belongs.

It follows that if a chattel, having a face value or other ascertainable value, is widely accepted in exchange for all other kinds of property, then it has to be regarded as money, whether or not it is also a unit of the sovereign currency, provided that the holder has the right to exchange it for legal tender. ${ }^{88}$

87 Wookey v Pole (1820) 4 B \& Ald 1, (1820) 106 ER 839 (KB) at 7.

88 This is precisely the conclusion provided by the case the Court of Justice of the European Union in Skatteverket, above n 72, according to which bitcoins constitute a contractual means of payment and qualify as money at private law. 